\title{
CONSIDERATIONS OVER THE BIOGEOGRAPHY OF THE WEST MESOREGION OF MARANHÃO (BRAZIL)
}

\author{
Mayanna Karlla de Lima Costa ${ }^{1,}$; Lianne Pollianne Fernandes Araújo Chaves ${ }^{1}$; Raimunda Alves Silva ${ }^{2}$ \\ and Glécio Machado Siqueira ${ }^{3}$ \\ ${ }^{1}$ Doutoranda no Programa de Pós-Graduação BIONORTE, Universidade Federal do Maranhão, São Luís, Brazil. \\ ${ }^{2}$ Mestrando no Programa de Ciência Animal, Universidade Federal do Maranhão, São Luís, Brazil. ${ }^{3}$ Professor, \\ Departamento de Geociências, Universidade Federal do Maranhão, São Luís, Brazil. \\ * Corresponding author: mayannakarlla@hotmail.com
}

\begin{abstract}
The State of Maranhão has been presenting worrying data regarding the preservation of their ecosystems, being needed a greater knowledge of the State geographical space so that the mitigate measures of the environmental impacts may be adopted. Among the State mesoregions with the highest growth rate (average of $35 \%$ in the last 10 years), stands out to the west, located in the eastern Amazon. The mesoregion is formed by the union of 52 cities grouped into three microregions (Gurupi, Imperatriz, and Pindaré). The present article aims to study the main aspects of Biogeography of the Maranhão western region. The economy is based on maize, rice, babassu coconut extract, manioc, beef cattle that has been growing considerably in the recent years and still has great opportunities for investors in the mining sector. The area presents great biological diversity due to the presence of dense Rainforest, Cerrado domain and pioneer formations, which has been suffering deforestation and loss up to $70 \%$ of primitive vegetation. It has distinct geological structures, crystalline and sedimentary, with soils that present several characteristics highly weathered. The climate presents humid tropical and equatorial features and stands out for having a transition between the humid climate of the Amazon and the semi-arid of the Brazilian northeastern. The relief is divided into two areas: the one from the Center-North, comprised of plain relief and from the Center-South, which corresponds to a prolongation of the Brazilian central plateau. Biologically, this region houses the Biological Reserve of Gurupi (REBIO GURUPI), which presents great importance for the conservation of the Maranhense Amazon whose ecological and environmental importance contrasts with the intense dynamics of the human occupation.
\end{abstract}

Key words: Eastern Amazon, environmental conservation, geographical areas.

\section{CONSIDERAÇÕES SOBRE A BIOGEOGRAFIA DA MESORREGIÃO OESTE MARANHENSE (BRASIL)}

RESUMO: O Estado do Maranhão vem apresentando dados preocupantes quanto à preservação de seus ecossistemas, sendo necessário um maior conhecimento do espaço geográfico do Estado para que medidas mitigatórias possam ser tomadas. Dentre as mesorregiões do Estado com maior taxa de crescimento (média de 35\% nos últimos 10 anos), destaca-se a oeste, localizada na Amazônia Oriental. A mesorregião é formada pela união de 52 municípios agrupados em três microrregiões (Gurupi, Imperatriz e Pindaré). O presente artigo objetiva estudar os principais aspectos da Biogeografia da mesorregião Oeste Maranhense. A economia baseia-se nas culturas de milho, arroz, extração do coco babaçu, mandioca, pecuária de corte que vem crescendo consideravelmente nos últimos anos e ainda possui grandes oportunidades para investidores no segmento de mineração. A área apresenta grande diversidade biológica devido à presença da Floresta Ombrófila Densa, domínio de cerrado e formações pioneiras, que vem sofrendo desmatamento e perdas de até $70 \%$ da vegetação primitiva. Possui estruturas geológicas distintas, cristalinas e sedimentares, com solos que apresentam características diversas altamente intemperizados. O clima apresenta características tropicais úmidas e equatoriais e destaca-se por haver uma transição entre o clima úmido da Amazônia e o semi-árido do nordeste brasileiro. O relevo está dividido em duas áreas: a do centro-norte, formada por relevo de planície e as do centro-sul, que correspondem a um prolongamento do planalto central brasileiro. Biologicamente, essa região abriga a Reserva Biológica do Gurupi (REBIO GURUPI) que apresenta grande importância para a conservação ambiental da Amazônia Maranhense e cuja importância ecológica e ambiental contrasta com a intensa dinâmica de ocupação humana.

Palavras-chave: Amazônia oriental, conservação ambiental, áreas geográficas.

Received: Aug. 10, 2016 - Accepted: Nov. 24, 2016 


\section{INTRODUCTION}

The Biogeography is the portion of Biological Sciences in charge of explaining how the geographical distribution of organisms was formed, to this end, attention should be taken for the several aspects that characterize determined space being the main: the climate, the relief, the hydrography, the geology and the vegetation (Posadas, 2006)
Maranhão is one of nine states that form the Northeast region, occupies the western portion of the same and form together with the Piauí state the called Northern Middle or Western Northeast, the state presents both typical characters of the northern region regarding the northeast of the country region and has 217 cities divided into five mesoregions - Figure 1 (IBGE, 2016).

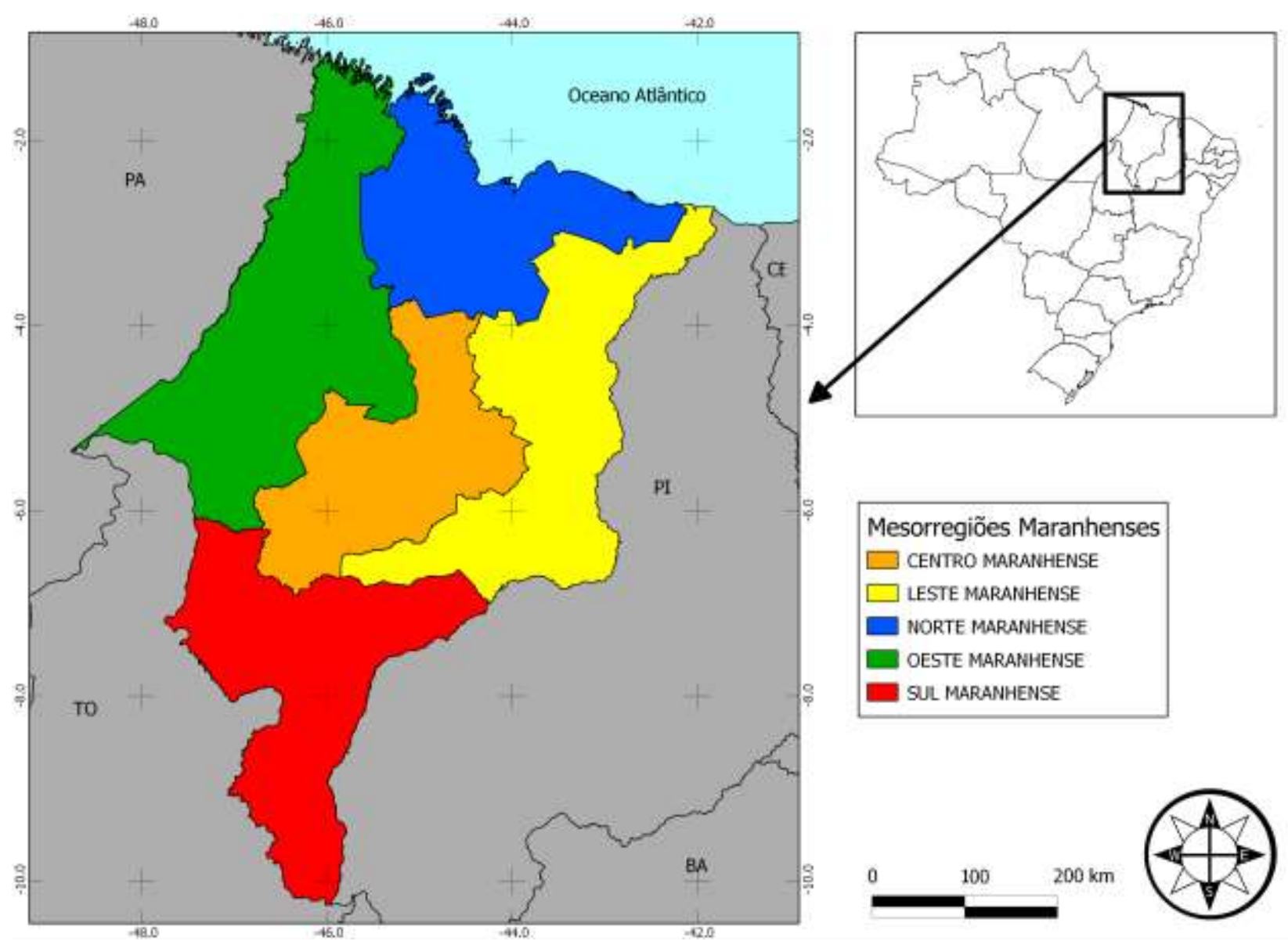

Figure 1. Mesoregions of the Maranhão State (Brazil).

The state is characterized by having one of the largest varieties of Brazil's ecosystems, however, has been presenting worrying data regarding the preservation of them, being therefore fundamental the knowledge of geographical space across the state so that the mitigate measures of the environmental impacts be adopted (PPCD - MA, 2007).

Among the state mesoregions with the highest growth rate (average of 35\% in the last 10 years), stands out the west 
mesoregion (Figure 2), located in the eastern Amazon. This growth is reflected by the occupation of the agricultural frontier, industrialization and the development

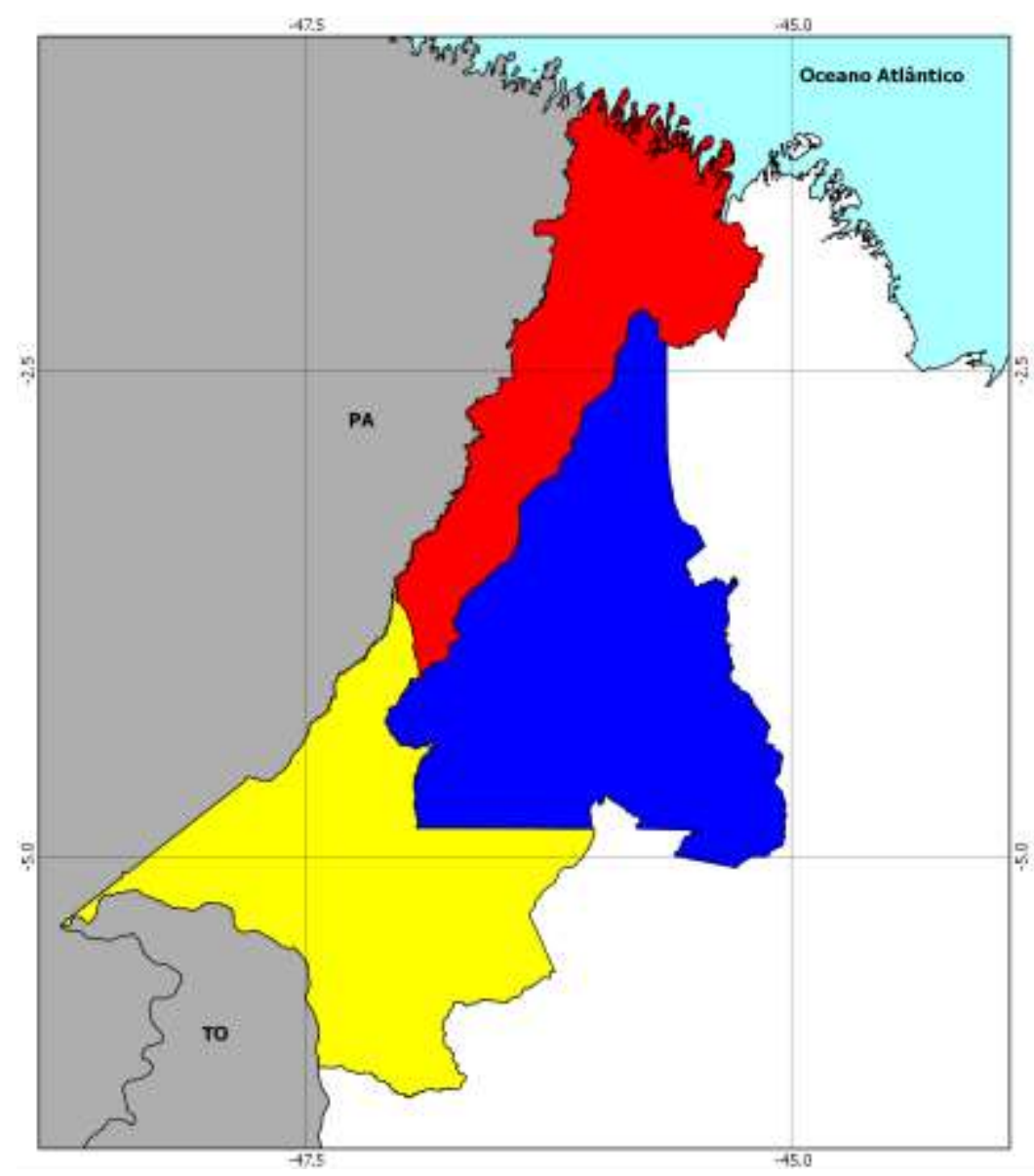

boosted by Carajás Railroad (Junior et al., 2009).

Figure 2. West Mesoregion of Maranhão (Brazil).

This mesoregion has great importance for environmental conservation, including the endemism Center in Belem, and a region rich in minerals resources and consequently endangered, integrating priority areas for conservation (Almeida and Vieira, 2010). Among the main devastation problems in this state portion, can be cited the pig iron steel mill, wood extraction, the increase of intensive livestock, the monoculture, the growth of cities and the opening of Roads that contribute to deforestation and burning, resulting in the loss of vegetation cover and also biodiversity (Martins e Oliveira, 2011).

From a geological point of view, this mesoregion stands out by having distinct geological structures, the crystalline and the sedimentary, resulting in several soil characteristics, with a predominance of tropical soils, highly weathered.

This review aims to study the main aspects of Biogeography of the west mesoregion of Maranhão, state portion, which occupies the eastern side of the Gurupi basins, of Pindaré high and medium course, the middle course 
of Grajaú and the Tocantins River, and which is formed by Gurupi, Imperatriz and Pindaré mesoregions, totaling 52 cities.

\section{MESOREGION ECONOMIC ASPECTS (AGRICULTURE E LIVESTOCK)}

The main economic region of Maranhão is where are located the valleys of the rivers Pindaré, Mearim, and Itapecuru, where concentrates most of the agricultural, pastoral and mining activities of the state. Maranhão western region is located in this portion and its economy is based on maize and rice culture and in the extraction of babassu coconut, is also the region with the largest cassava production rate, especially the cities of Zé Doca, Centro Novo do Maranhão, Bom Jardim, Nova Olinda do Maranhão, Presidente Médici, Pedro do Rosário and Maracaçumé.

The beef cattle industry is also an economic activity of great importance and growth in Maranhão west mesoregion. According to the Statistics of Livestock Production, the last quarter of 2015, released by the Brazilian Institute of Geography and Statistics (IBGE), Maranhão ended the year 2015 with growth of $7.9 \%$ in the number of slaughtered cattle under some kind of sanitary inspection service in relation to 2014, going against the country, which recorded a reduction of $9.6 \%$ in the same period, and much of this production comes from the regions of Açailândia, Santa Luzia, Imperatriz and Riachão.

Besides agriculture and livestock, Maranhão west region presents a scenario of great opportunities for investors in the mining sector, because it has natural conditions, as a vast territory extension; hydric resources, besides strategic location for the international market, by having large access railroads. Among the potential of this region, can be highlighted the extraction of gold in the Gurupi region, with an auriferous province of an area higher than 30,000 $\mathrm{km}^{2}$. Only in 2013, the production of a mining installed in the region was 79,229 (oz), with CFEM collection of 2.5 million and with a projection of future expansion to 250,000 oz and national CFEM collection of 6.6 million. Gold is responsible for over $65 \%$ of the collection of Maranhão CFEM (IBGE 2016).

\section{CLIMATE, RELIEF, SOIL TYPES E VEGETATION}

The knowledge of the climatic type of a region, just as its relief, vegetation and pedology are important subsidies for the planning of several human activities, as well as to decision-making in cases of environmental conservation measures.

For the proper understanding of Maranhão West Mesoregion relief, initially, fits the same in several classifications of relief at the national level, to classify it finally according to the geomorphological peculiarities of the State. Maranhão West Mesoregion about to its relief is divided into two areas: the centernorthern, formed by plains relief and the center-south, which corresponds to a prolongation of the Brazilian central plateau, owning in a greater portion area contained in the plains and coastal lowlands and the rest belongs to the Plateau of Maranhão-Piaui. The same has an area with an altitude below 200 meters, classified as plain, and surfaces that overcome this altitude, framed in the geo-form plateau. 
Maranhão West Mesoregion Maranhão is formed by the following morpho-sculptural units: Surfaces and trays in the rain forest region, which are contained the surfaces of the Gurupi and Baixo Gurupi and the hills and ridges of the Gurupi; Plateaus in the region of Seasonal and Rain Forests, where includes the Dissected Plateau of Pindaré/Grajaú; Chapada, Board and Depression in the Ecological Tension Area Savannah/Seasonal Forest, where is contained the Chapada de Imperatriz.
From the latest classification of the IBGE (2011), is deduced the following geomorphological units in Maranhão West Mesoregion: a) Coast of Mangroves and river branches; b) Surface of the Baixo Gurupi; c) hills and ridges of Gurupi; d) Dissected surface of Santa Luzia do Paruá; e) Depression of Gurupi; f) Dissected Plateau of Gurupi-Grajaú; g) Imperatriz Depression h) Fluvial Plains.

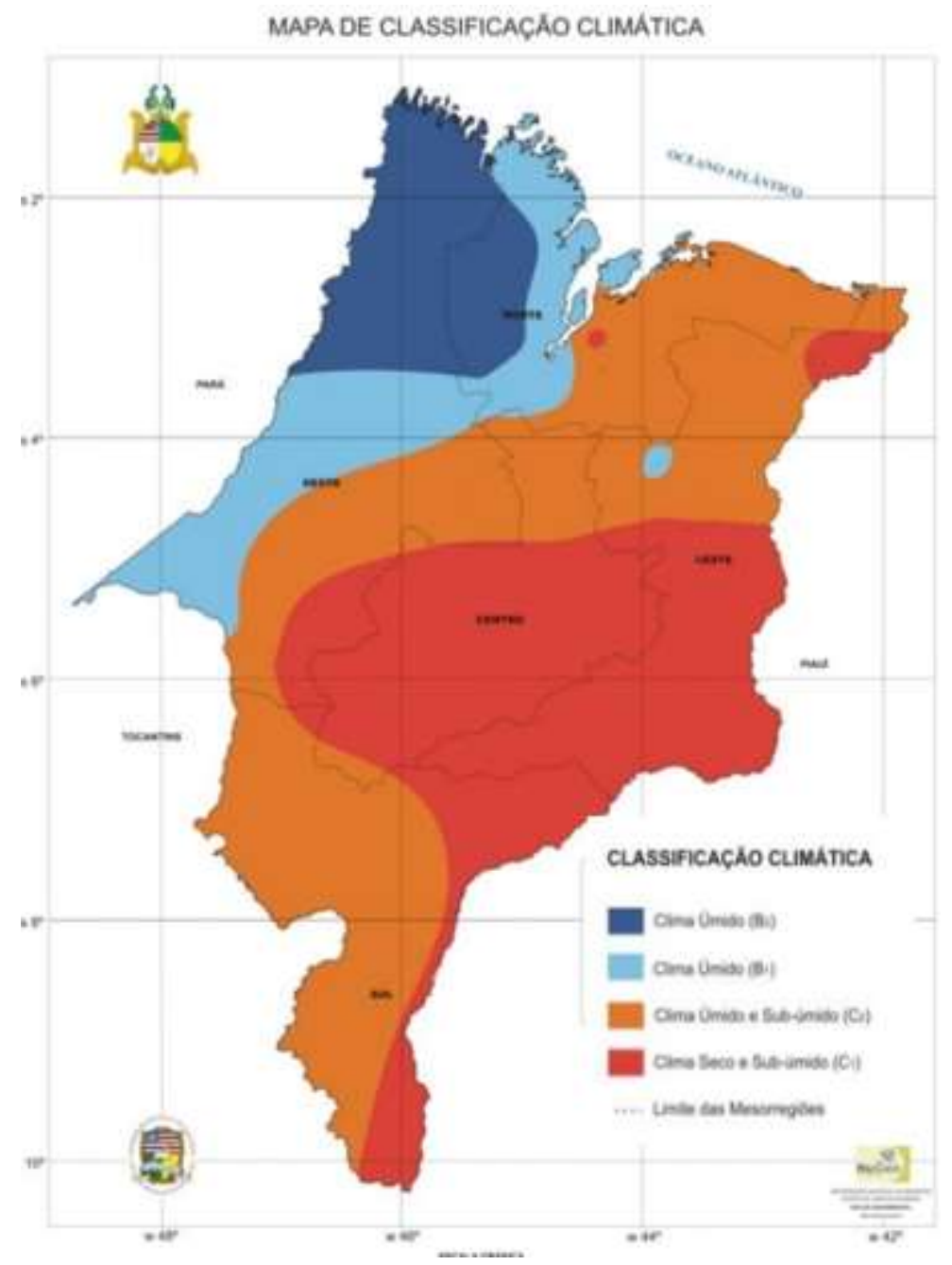

Figure 3. Map of climate classification of Maranhão State(Brazil). 
Regarding the weather, the state of Maranhão is located in an area controlled entirely by hot air masses, and therefore the monthly temperature values remain high the entire year. Rainfalls behave seasonally, with striking alternation between the dry and rainy season, this feature that is summarized in a climatic pattern Tropical Semi-moist, the average annual rainfall is $1546.7 \mathrm{~mm}$, with the highest monthly average in March (294.1 $\mathrm{mm}$ ) and lowest monthly average in July and August ( 8.1 and $8.3 \mathrm{~mm}$, respectively).

Maranhão West Mesoregion Maranhão _ stands out because there is a transition between the moist climate of Amazon and the Brazilian northeastern semi-arid. In this part of the state two moist climatic types stand out: B1WA'a'- moist climate type (B1); B2r A'a'- moist climate type (B2) as can be observed in Figure 3. The annual thermal scheme presents high temperatures, with an annual average of $25.9^{\circ} \mathrm{C}$, a maximum annual average of $32.8^{\circ} \mathrm{C}$ and a minimum average of $20.2^{\circ} \mathrm{C}$.

This part of the state is covered almost in its entirety by the Amazon Biome (Figure 4), being the same characterized by being composed of several ecosystems. Has as main vegetation dense and open Rain that reflects transactionality of the territory, additionally has a great heterogeneity of fauna and flora species (Almeida et al., 2005; Dornas et al., 2014; Serra et al., 2016). In relation of pedology of this mesoregion the predominant types of soils are distributed in the Microregions,: Gurupi predominate the soil classes : Gleysols and Yellow Latosol (IBGE, 2011), which occur with greater predominance in the cities of Turiaçu, Amapá of Maranhão and Carutapera, also if has the Petric Plinthosols, Haplic Plinthosols
Eutrophic Argiluvic and aluminium and in a minority of Dystrophic Cohesive Yellow Latosols occurring in the cities of Turilândia, Luis Domingues, Maranhãozinho, Centro do Guilherme and throughout the western portion, on the Gurupi riverside. In Pindaré Microregion, Pale Chromic Luvisols and Orthic Chromic Luvisols are found in the cities of Vitorino Freire, Paulo Ramos, Lago da Pedra, Brejo de Areia and Altamira do Maranhão (Carvalho, 2011).

In the remaining, in the northern portion of the microregion, the cities of Governador Newton Bello, Bom Jardim, Alto Alegre do Pindaré, Santa Luzia, Presidente Médici, Santa Luzia, Santa Luzia do Paruá, Nova Olinda from Maranhão and Araguanã predominates the Litoplíntic Petric Plinthosol, at most part, with smaller strips of Aluminium Argiluvic Plinthosol. The city of Santa Inês covers an area with Argiluvic Plinthosol.

In the microregion of Imperatriz, predominates the Dystrophic Cohesive Yellow Latosols in all the center of this microregion. There is also a wide range of Red-Yellow Dystrophic Argisols between the areas of Dystrophic Cohesive Yellow Latosols. Appear, however in smaller strips the Eutrophic Haplic Plinthosols, Orthic Ebanic Vertisols, Orthic Chromic Luvisols and in the track of Maranhão extreme west close to the Bico do Papagaio there is a large area of Eutrophic Yellow- Argisols. (IBGE, 2011).

\section{CONSERVATION UNIT}

The Maranhão state consists of 26 conservation units, being 14 under state jurisdiction and 12 under federal jurisdiction (Law No. 9,985 of July 18, 2000), among the 
main state biological reserves stands out the Gurupi Biological Reserve, Federal Conservation Unit (CU), Whose management is carried out by Chico Mendes Institute for Biodiversity Conservation (ICMBio), which is located in the western portion of Maranhão state, partially comprises the cities of the new center of Maranhão (59.08\%), Bom Jardim (35.59\%), and São João do Carú (5.33\%), adding up it has 271,197.51 hectares of protected area (Figure 5).

Gurupi Rebio is the only CU located in Maranhense Amazon area, having fundamental importance in the environmental conservation throughout the state, it has the Gurupi River on the west boundary of the UC, being also the boundary between the states of Maranhão and Pará, and even the indigenous reserve from Alto
Turiaçu to the north, Caru and Awa to the west (Moura et al., 2011; IBAMA, 2016).

The scenario of ecological and environmental importance of the Gurupi Biological Reserve contrasts with the sharp increase in demographic density in this mesoregion, which has its natural landscape of mixed forest with open areas, besides villages and farms, moreover, the reserve has constant threats of habitat loss, degradation, fragmentation caused by the deforestation, do selective wood extraction, vehicle traffic, hunting and fishing activities, and many other anthropic activities (Almeida and Vieira, 2010; Oliveira 2011).
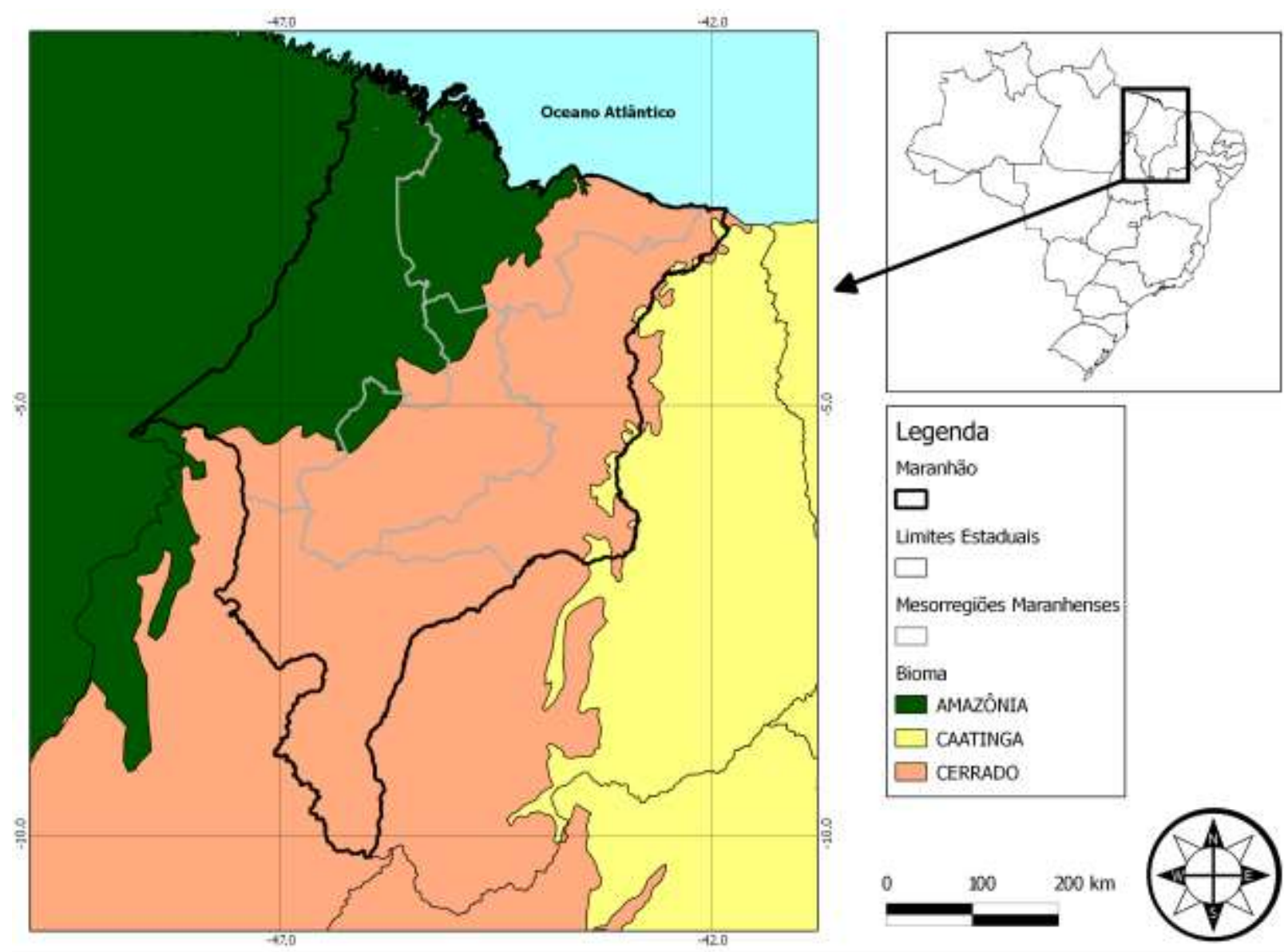
Figure 4. Distribution of the biomes in the Maranhão State (Brazil).
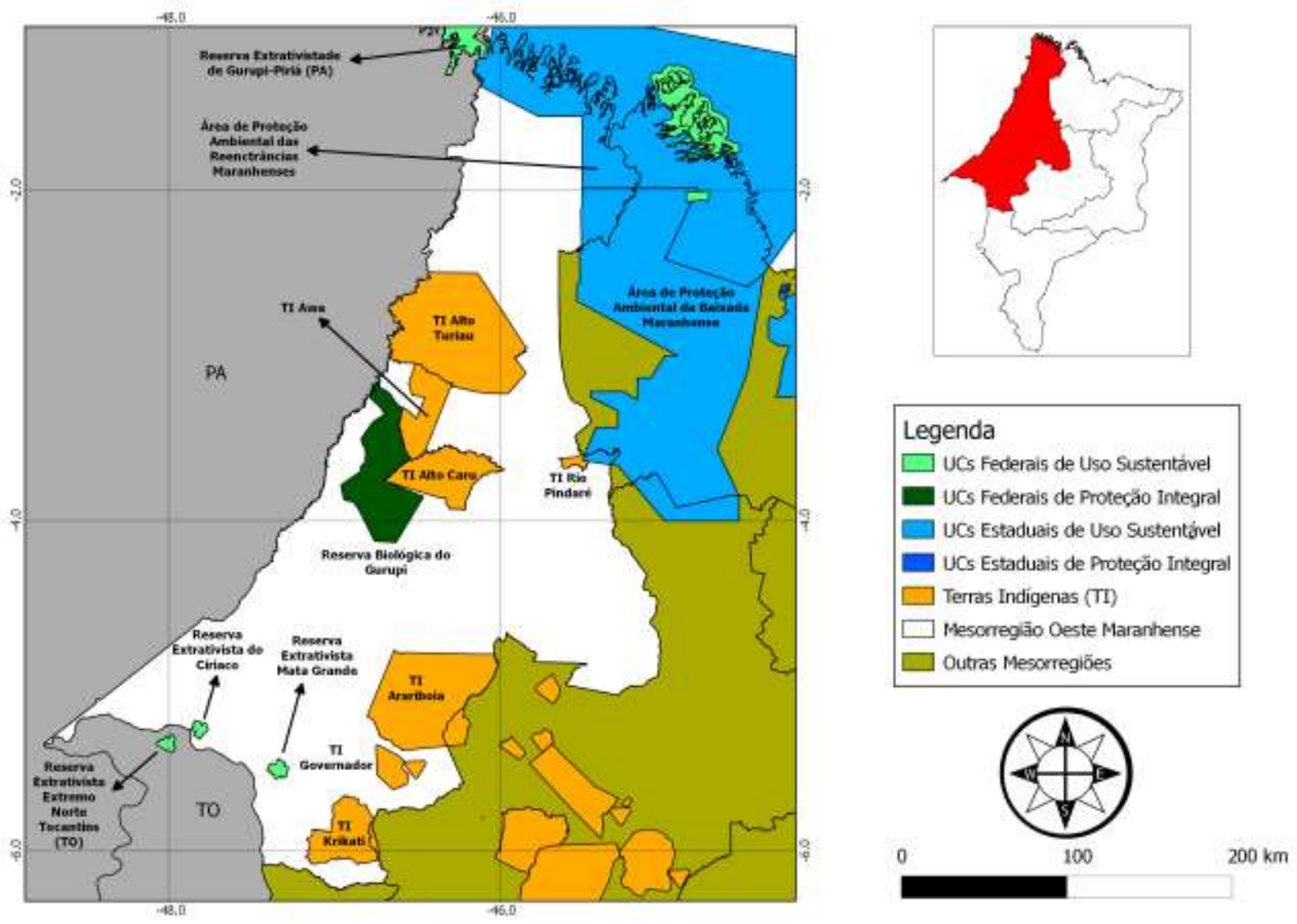

Figure 5. Conservation units of the West Mesoregion of Maranhão State (Brazil).

Maranhense Amazon owns rich biodiversity, occupies 26\% of the Amazon biome, and lies in 62 cities of Maranhão and represents, in terms of the biome, $34 \%$ of the state territory. However, it takes a serious risk of disappearing. For years has been suffering from deforestation, illegal wood removal, mining, charcoal production, excessive hunting, and cattle raising. Both Maranhense Amazon as a whole and the Gurupi especially, are vital to the survival of two species of primates, the Ka'apor Capuchin (Cebus kaapori) considered critically endangered and that basically exists only in this region, as well as black-bearded saki (Chiropotes satanas) (Figures 6a and 6b, respectively).
This area is also the refuge of the last populations of tapir (Tapirus terretris), whitelipped peccary (Tayassu pecari), species not traditionally threatened (but considered in the vulnerable category in Maranhão Oliveira, 1997), beyond those mentioned, are present in the list of endangered species protected in this Conservation Unit the gatodo-mato (Leopardus tigrinus); mutum-depenacho (Crax fasciolata pinima); arapaçubarrado (Dendrocolaptes certhia medius); gato-maracajá (Leopardus pardalis mitis); onça-pintada (Panthera onca); mãe-de-taocapintada (Phlegopsis nigromaculata paraensis); araçari-de-pescoço-vermelho (Pteroglossus bitorquatus bitorquatus); jacamim-de-costas- 
verdes (Psophia viridis) and tiriba-pérola

(Pyrrhura lepida lépida) (ICMBIO, 2016).

a)

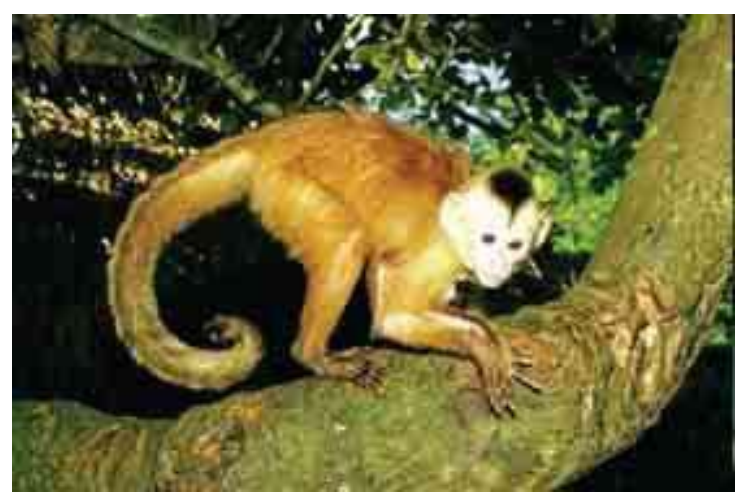

b)

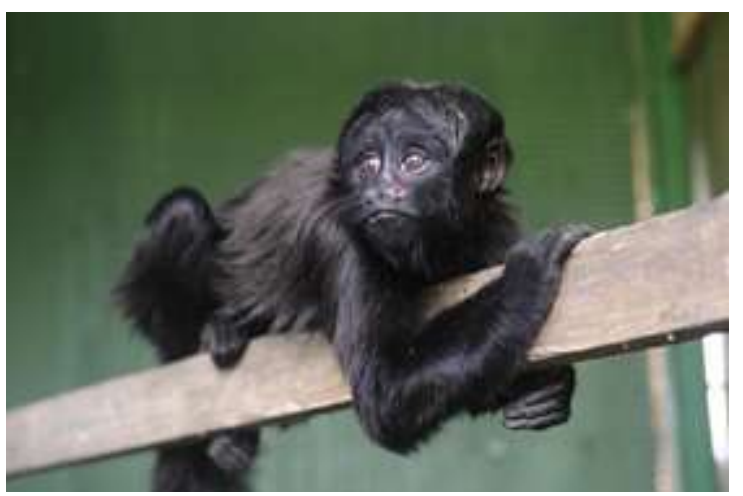

Figure 6. a) Ka'apor Capuchin (Cebus kaapori) and b) Black-bearded saki (Chiropotes satanas).

According to the study "Maranhense Amazon: diversity and conservation" released in 2011 as a result of a partnership between the Research Program on Eastern Amazon Biodiversity (PPBio), Paraense Emilio Goeldi Museum (MPEG), Ministry of Science, Technology and Innovation (MCTI) and the Environment (MMA), It is about "one of the most expressive portions in terms of species richness and endemism".

\section{FINAL CONSIDERATIONS}

Maranhão West Mesoregion is characterized mainly by having climatic and phytoecological characteristics of the Amazon region. It is a portion of the state that has highest growing in the last years, both demographically, but also economically through agricultural sectors. It comprises an area with great biodiversity due to the presence of dense Rainforest, savannah parts and pioneer formations, featured by the presence of deforestation.
Presents varied geological structure, comprising both crystalline material and sedimentary, with great wealth mineralogical under the cratonic material present in Gurupi section, with the occurrence of iron, gold, and manganese. Pedologically, due to high moist accumulation in pedogenetic horizons, there is a high occurrence of highly weathered tropical soils.

In this state mesoregion is located the Gurupi REBIO that presents great importance for the environmental conservation of the Maranhense Amazon, however, this scenario of the ecological and environmental importance of Gurupi Biological Reserve contrasts with the intense dynamics of human occupation.

\section{REFERENCES}

Almeida, A.S.; Vieira, I.C.G. 2010. Centro de Endemismo de Belém: Status da vegetação remanescente e desafios para a conservação da biodiversidade e restauração ecológica. Revista de Estudos Universitários (REU), v. 36, n. 3, p. 95-111, dez 2010. Disponível em: 
<http://repositorio.museugoeldi.br/jspui/handle/123456789/547>. Acesso em: 21 de set. 2016.

ATLAS DO MARANHÃO. 2002. Gerência de Planejamento e Desenvolvimento Econômico, Laboratório de Geoprocessamento - UEMA. São Luís: GEPLAN.

Carvalho Filho, R. 2011. Solos do Estado do Maranhão. In: Seminário sobre Aspectos Geoambientais e Socioeconômicos do Maranhão. São Luis: SAGRIMA.

Costa, F.R.C 2005. Protocolo para amostragem de vegetacao nas parcelas permanentes do PPBio. In: Magnussom, W.; Martins, M.B. (rel.), Delineamento Espacial e Protocolos de Coleta - PPBio Amazônia, MCT/INPA/MPEG. p. 60-79.

Dornas, T; Pinheiro, R.T.; Corrêa, A.G.; Prado, A.D. 2014. Novos registros e implicações sobre a ocorrência de Celeus obrieni, picapau-do-parnaíba no cerrado norte e amazônia maranhense. Ornithologia, v.7, n. 1.

IBAMA. 1999. Instituto Brasileiro de Meio Ambiente e Recursos Naturais Renováveis. Plano de Manejo da Reserva Biológica do Gurupi. Brasília, junho de 1999. Disponível em:

http://www.icmbio.gov.br/portal/biodiversida de/unidades-de

conservacao/biomasbrasileiros/amazonia/uni dades-de-conservacao-amazonia/1998 rebiodo-gurupi.html Acesso em 22 set 2016

IBGE. 1992. Diretoria de Geociências. Departamento de Recursos Naturais e Estudos Ambientais. Manual técnico da vegetação brasileira. Rio de Janeiro, 1992. 92p. (Sér. Manuais Técnicos em Geociências, $1)$.

IBGE. 2011. Instituto Brasileiro de Geografia e Estatística. Coordenação de Recursos Naturais e Estudos Ambientais. Mapa Pedológico do Maranhão, 1ạ Edição, 2011.
Disponível em: ftp://geoftp.ibge.gov.br/mapas_tematicos/pe dologia/unidades_federacao/ma_pedologia.p $\mathrm{df}$

ICMBIO. 2016. Instituto Chico Mendes de Conservação da Biodiversidade. Disponível em: <http://www.icmbio.gov.br>. Acesso em 21 set 2016.

MARANHÃO. 2011. Plano de Ação para a Prevenção e Controle do Desmatamento e das Queimadas no Estado do Maranhão PPCD - MA, 2011 Instituído pelo Decreto no 27.317, de 14 de abril de 2011.

Martins, M.B.O. 2011. Programa de Pesquisa em Biodiversidade na Amazônia Maranhense. In: Martins, M B.; Oliveira, T. G. de. Amazônia Maranhense: Diversidade e Conservação. Belém: MPEG, 2011. cap. 01, p.17- 24

Moura, W.C.; Fukuda, J.C.; Lisboa, E. A. 2011. A Reserva Biológica do Gurupi como instrumento de conservação da Amazônia Oriental. In: Martins, M B.; Oliveira, T. G. de. Amazônia Maranhense: Diversidade e Conservação. Belém: MPEG, 2011. cap. 01, p. 25-34.

Posadas, P.; Crisci, J.V.; Katinas, L. 2006. Historical biogeography: a review of its basic concepts and critical issues. Journal of Arid Environments 66, 389-403.

Ribeiro Júnior, J.A.S.; Sant'ana Júnior, H.A. 2011. A geografia política dos conflitos ambientais no Maranhão: território, desenvolvimento e poder no Relatório de Sustentabilidade da Vale 2009. Revista Percurso/NEMO. Maringá, v. 3, n. 1, 107-123.

Richetti, P.; Costa, J.M. 2010. O Natural e o Social na crise ambiental: Considerações sobre políticas territoriais na Amazônia Oriental. In: VIII Congresso Latino Americano de Sociologia Rural, Anais... Porto de Galinhas (PE). 